\title{
Development of priority markets in the region as a factor of increasing its competitiveness
}

\author{
Irina Shashkova \\ Ryazan State Agrotechnological \\ University Named after P.A. Kostychev \\ Department of Economics and Management \\ Ryazan, Russia \\ irina@rgatu.ru
}

\author{
Larisa Romanova \\ Ryazan State Agrotechnological \\ University Named after P.A. Kostychev \\ Department of Economics and Management \\ Ryazan, Russia \\ lara.romanova80@yandex.ru
}

\begin{abstract}
The article presents analysis of 'the regional competitiveness'. The essence of competitiveness of the region is determined. The investment potential of Ryazan oblast is analyzed in terms of its main components. Priority markets of the region have been identified to increase the level of its competitiveness. Directions for their further development are proposed.
\end{abstract}

Keywords - competitiveness of the region, competitive environment, investment potential, investment risk, priority markets

\section{INTRODUCTION}

Studying the competitiveness of regions in current economic conditions is of great importance for developing strategies for their further development. The purpose of the research is studying the state of the competitive environment at Ryazan oblast markets, analyzing the investment potential of the region and identifying priority markets for its further development.

\section{MATERIALS AND Methods (MODEL)}

In modern economic conceptual tools, 'regional competitiveness' is most often considered as 'the ability to create conditions at domestic and foreign markets'. According to A.A. Seleznev, the region's competitiveness is understood as the position of the region and its individual commodity producers at the domestic and foreign markets, which is determined by economic, social, political and other factors, expressed through certain indicators [1]. V.V. Pechatkin, S.U. Salikhov, V.A. Sablina, A.Z. Selezneva, Z.A. Vasilyeva, M. Porter, V.Yu. Shubin et al suppose that the regional competitiveness is inextricably linked with the notion of 'competitive environment' at markets of the territory under consideration', i.e. with the ability of the economy of the region under study to produce and consume goods and services in a competitive environment [1]. We agree with the authors and believe that the increase of the regional competitiveness is due to the development of the competitive environment at socially important markets in the context of a particular territory. The increase of the competitive environment at regional markets, in its turn, influences the level of the regional investment attractiveness, the standard of living of the population and the efficiency of resource use (Fig.1).

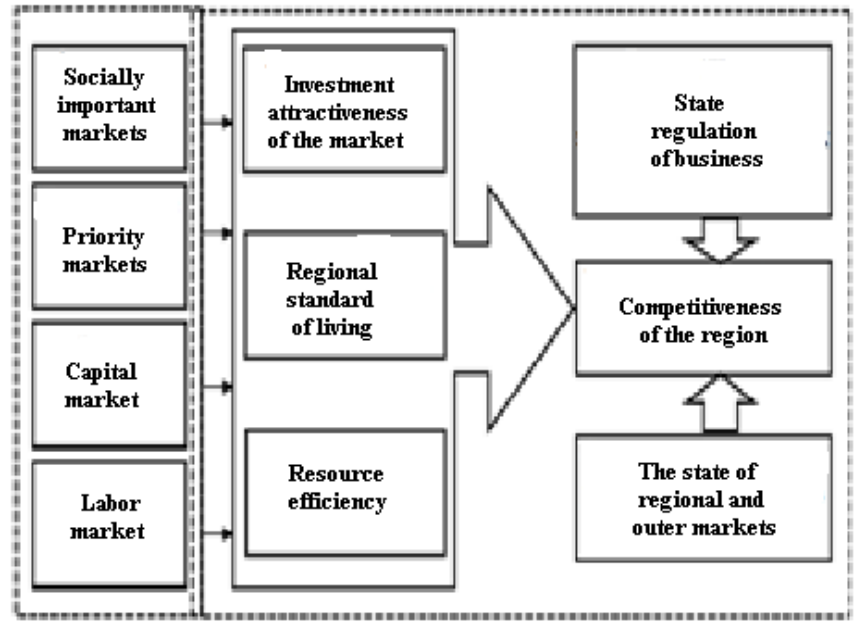

Fig.1. Basic elements of the regional competitiveness

The report of the Ministry of Economic Development and Trade of Ryazan oblast on the state and development of the competitive environment at markets of goods, works and services of the region reflects the current state of competitiveness at socially important markets of the region, which include: the market for pre-school education, children's recreation and rehabilitation, health services, social services for the population, services in the sphere of culture, housing maintenance and utilities, retail market, communication services, passenger transportation by land transport [3]. Increasing the level of the competitive environment at these markets in accordance with the "Standard of competition development in the constituent entities of the Russian Federation" can be achieved due to the effective use of regional budget funds, which in turn increases the standard of living and investment attractiveness of the region [4].

\section{RESULTS AND DISCUSSION}

The investment attractiveness of the region is estimated by two indicators: the investment potential and the investment risk of a particular territory. The investment potential takes 
into account the basic macroeconomic characteristics of the region: factors of production, availability of labor resources, processing enterprises, infrastructure development and a number of other parameters.

Our analysis of the total investment potential of Ryazan oblast from 1996 to 2017 based on the data of the rating agency "Expert $\mathrm{Ra}^{\prime}$ in terms of its components (labor, financial, production, consumer, institutional, infrastructure, natural resources, tourism, innovation) revealed a tendency to reduce investment risk (TABLE I) [5].

TABLE I. DYNAMICS OF INVESTMENT POTENTIAL OF RYAZAN OBLAST FOR 1996-2017

\begin{tabular}{|c|c|c|c|c|c|c|c|c|c|c|c|c|}
\hline$\grave{\succsim}$ & 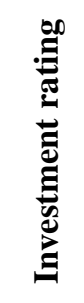 & 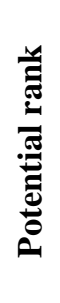 & 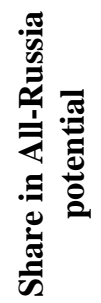 & $\frac{\grave{8}}{\tilde{\Xi}}$ & 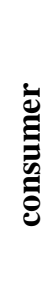 &  & 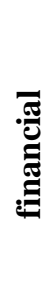 &  &  &  &  &  \\
\hline 1996 & $1 \mathrm{C}$ & 15 & - & - & 47 & 44 & - & 43 & 8 & 20 & 38 & - \\
\hline 1997 & $2 B$ & 37 & - & - & 43 & 47 & - & 42 & 29 & 21 & 38 & - \\
\hline 1998 & 3B1 & 44 & 0.739 & 46 & 49 & 47 & 45 & 42 & 26 & 20 & 55 & - \\
\hline 1999 & 3B1 & 45 & 0.74 & 55 & 49 & 42 & 35 & 40 & 35 & 22 & 54 & - \\
\hline 2000 & 3B1 & 52 & 0.62 & 39 & 51 & 48 & 51 & 42 & 42 & 24 & 54 & - \\
\hline 2001 & 3B1 & 51 & 0.64 & 35 & 54 & 45 & 52 & 43 & 42 & 22 & 54 & - \\
\hline 2002 & 3B1 & 51 & 0.62 & 43 & 49 & 46 & 43 & 41 & 46 & 23 & 54 & - \\
\hline 2003 & 3B1 & 45 & 0.70 & 40 & 50 & 37 & 43 & 40 & 43 & 21 & 59 & - \\
\hline 2004 & 3B1 & 48 & 0.62 & 42 & 49 & 40 & 45 & 46 & 42 & 22 & 56 & - \\
\hline 2005 & 3B1 & 50 & 0.597 & 36 & 51 & 44 & 49 & 48 & 41 & 22 & 56 & 44 \\
\hline 2006 & 3B1 & 51 & 0.607 & 42 & 48 & 40 & 48 & 51 & 45 & 20 & 55 & 31 \\
\hline 2007 & 3B1 & 50 & 0.614 & 44 & 51 & 40 & 50 & 49 & 48 & 18 & 57 & 30 \\
\hline 2008 & 3B1 & 50 & 0.623 & 44 & 50 & 43 & 48 & 47 & 48 & 19 & 59 & 32 \\
\hline 2009 & 3B1 & 51 & 0.672 & 42 & 44 & 45 & 45 & 42 & 49 & 28 & 53 & 43 \\
\hline 2010 & 3B1 & 52 & 0.679 & 43 & 44 & 44 & 47 & 47 & 56 & 16 & 53 & 44 \\
\hline 2011 & 3B1 & 49 & 0.685 & 51 & 50 & 44 & 48 & 48 & 31 & 24 & 55 & 42 \\
\hline 2012 & 3B1 & 53 & 0.659 & 48 & 49 & 43 & 51 & 47 & 32 & 31 & 55 & 42 \\
\hline 2013 & 3B1 & 53 & 0.643 & 49 & 47 & 42 & 51 & 45 & 46 & 33 & 55 & 39 \\
\hline 2014 & 3B1 & 51 & 0.675 & 46 & 46 & 42 & 50 & 49 & 41 & 34 & 55 & 38 \\
\hline 2015 & 3B1 & 52 & 0.679 & 45 & 44 & 43 & 49 & 42 & 42 & 34 & 56 & 40 \\
\hline 2016 & 3B1 & 53 & 0.700 & 46 & 46 & 43 & 51 & 48 & 38 & 34 & 55 & 42 \\
\hline 2017 & $3 \mathrm{~A} 1$ & 49 & 0.684 & 43 & 49 & 41 & 50 & 46 & 38 & 33 & 57 & 39 \\
\hline
\end{tabular}

So, in 2017 , the region was first assigned a rating of $3 \mathrm{~A} 1$, i.e. investment risk from the "moderate" category moved to the "minimum risk" category.

It should be pointed out that the best indicators in the investment potential rating according to the rating agency "Expert Ra" were shown by the regions, who pay attention to the development of agro-food markets and the competitive environment at these markets. For example, Belgorod and Bryansk oblasts have an active increase in the rates of beef production and processing in recent years, which has moved Belgorod oblast from the $8^{\text {th }}$ to the $7^{\text {th }}$ position by investment risk and Bryansk oblast from the $36^{\text {th }}$ to the $31^{\text {st }}$ place respectively [5]. Therefore, the development of the competitive environment at food markets of regions is the main market method for stimulating production and reducing intermediaries when selling products.

One of the mechanisms for increasing the competitiveness of the region and investment attractiveness of the region is, in our opinion, the development of priority markets. The market for the production and processing of agricultural products and the market of tourist services can be classified as such in Ryazan oblast. The perspective development of industry and tourism is proved by the regional production potential that has achieved value 41 for the first time during 10 years. This indicates the need for further development of the production sector in the region, that is the production and processing of agro-food products (TABLE I). 
The production potential reflects the regional abilities to produce products, which are estimated as the value of fixed production assets and gross production. The minimum value of the production potential of Ryazan oblast equal to 37 was observed in 2003 and the maximum one equal to 48 was in 2000. The average value for the analyzed period was 43.2. Ryazan oblast belongs to the regions with developed agriculture, situated close to the largest markets for agricultural products: Moscow and Moscow oblast. Among the main factors restraining the development of competition at the agrofood market of the region one can mention the following ones:

- $\quad$ insufficient processing capacity;

- $\quad$ high percentage of wear and tear on agricultural plant and equipment;

- lack of own material and financial resources at processing and agro-industrial enterprises.

The main tasks of the development of this priority market in order to improve the competitiveness of the region, in our opinion, should be:

- $\quad$ investing modernization and technical re-equipment of production, introducing resource-saving technologies and building new agricultural and food industry enterprises;

- escalation of opportunities to enter the market of new commodity producers due to direct sales of agricultural products.

The market of tourist services also belongs to priority markets of Ryazan oblast, contributing to the development of the region's competitiveness as a whole. The tourist potential of the oblast in 2017 was 39, i.e. increased by two points and this was the best result since 2008 . There has been some steady growth in recent indicators characterizing the development of tourism in the region, which is proved by the results of the investment potential rating for the tourist component. So, the volume of tourists flow in the region in 2017 was 310 thousand people, which were $6.7 \%$ higher than that in the previous year and $13.3 \%$ higher than in 2015.

The cluster model is most acceptable for the development of the tourism sector. The use of the cluster model with the introduction of industrial enterprises usually gives the greatest economic effect for the development of the regional economy [2]. But in our opinion, clustering is also relevant for service companies. Now, the largest investment project in the sphere of tourism "Creation of a tourist and recreational cluster Ryazan" is being implemented on definitions of public-private partnership in Ryazan oblast. This project is implemented within the framework of the long-term target program "Development of domestic and incoming tourism in Ryazan oblast".

In this case, cluster is a point of internal growth for the regional economy. At the same time, the successful use of regional features can become a source of development of the region's competitiveness. The development of a tourist cluster in the region can be one of important components of the policy to develop the competitiveness of regional tourism services enterprises.

\section{CONCLUSION}

Thus, the competitiveness of the region is inextricably linked with the competitiveness of products, produced on the given territory. So, the choice of strategy for increasing the competitiveness of the region should be justified from the position of developing competitive industries on the territory under study. In connection with this, choosing priority sectors, which are potential in terms of the greatest impact for increasing the competitiveness of the entire region, is of great importance

Determining priority sectors for the development of the region is possible by means of successive implementation of the following stages:

- analysis of existing state measures to increase the competitiveness of the economy of a particular territory;

- $\quad$ setting goals and objectives for the development of the region, which are expressed in the form of specified indicators of socio-economic development;

- evaluation of the investment attractiveness of the region and its main components;

- identification of priority areas for territorial development, promoting the level of its competitiveness;

- development of new strategies or revision of existing regional development programs;

- choosing alternative tools and mechanisms for implementing priority directions to increase the competitiveness of the region.

It is advisable to evaluate the effectiveness of state policy and competitive advantages of a particular territory with the help of integral and composite indices, which will allow identifying problem areas and competitive advantages of the region in relation to others. The goal-setting and definition of the regional development objectives is an integral part of effective regional policy. The main goals of the territorial development are: the development of the competitive environment, stimulation of entrepreneurial and innovative activities, raising the standard of living of the population, etc. The main development goals are decomposed into more specific tasks, formalized in indicators of socio-economic development.

Selection of priority directions for the development of the region's economy should be based on an assessment of its investment potential and risk. These indicators, as well as territorial socio-economic features of development should be taken into account when developing new program methods and strategies for the regional development. One of the key elements in the implementation of the policy to increase the competitiveness of the region is creating some regional clusters. To ensure the further economic growth of the identified dominant sectors of the region's development, it is 
necessary to develop specific program activities, increasing the level of social and economic development of the region as a whole, and also realizing business interests of manufacturers and satisfying the needs of the population.

When choosing the instruments for implementing priority directions to enhance competitiveness of the region, it is reasonable to use the following groups of measures:

- creation of favorable conditions for business activities;

- $\quad$ state support of regional producers of food products in export activities;

- measures increasing demand for products of regional producers.

\section{References}

[1] A.H. Avezov. Sh. Rahimi. "Bulletin of Cherepovets State University" [Vestnik Cherepoveckogo gosudarstvennogo universiteta]. vol. 1. pp. 6265. January 2013.

[2] S.N. Smirnov. Yu.V. Simachev. L.S. Zasimova. A.A. Stocking. "Mechanisms for improving the competitiveness of the economies of regions" [Mekhanizmy povysheniya konkurentosposobnosti ekonomiki regionov]. Moscow: State University Higher School of Economics. 2005. pp. 61-64.

[3] "The state and development of the competitive environment in the markets of goods. works and services of the Ryazan region in 2017: Report of the Ministry of Economic Development and Trade of the Ryazan Region" [Sostoyaniye i razvitiye konkurentnoy sredy na rynkakh tovarov. rabot $\mathrm{i}$ uslug ryazanskoy oblasti v 2017 godu : Doklad Ministerstva ekonomicheskogo razvitiya i torgovli Ryazanskoy oblasti] Available at: https://mineconom.ryazangov.ru/. (accessed 31 January 2018).

[4] "Standard of development of competition in the subjects of the Russian Federation: Order of the Government of the Russian Federation of 05.09.2015 No. 1738-r" [Standart razvitiya konkurentsii v sub'yektakh Rossiyskoy Federatsii : Rasporyazheniye pravitel'stva Rossiyskoy Federatsii ot 05.09.2015 № 1738-r] Available at: http://www.pravo.gov.ru. (accessed 30 January 2018).

[5] "Expert Ra: rating agency" [Ekspert Ra: reytingovoye agentstvo] Available at: https://raexpert.ru/. (accessed 30 January 2018). 